\title{
Nrf2 Upregulates ATP Binding Cassette Transporter Expression and Activity at the Blood-Brain and Blood-Spinal Cord Barriers
}

\author{
Xueqian Wang, Christopher R. Campos, John C. Peart, Lindsay K. Smith, Jessica L. Boni, Ronald E. Cannon, \\ and David S. Miller \\ Laboratory of Toxicology and Pharmacology, National Institute of Environmental Health Sciences, National Institutes of Health, Research Triangle Park, \\ North Carolina 27709
}

Activation of nuclear factor E2-related factor-2 (Nrf2), a sensor of oxidative stress, is neuroprotective in animal models of cerebral ischemia, traumatic brain injury, subarachnoid hemorrhage, and spinal cord injury. We show here that Nrf2 activation with sulforaphane (SFN) in vivo or in vitro increases expression and transport activity of three ATP-driven drug efflux pumps at the blood-brain barrier [P-glycoprotein, ATP binding cassette b1 (Abcb1); multidrug resistance-associated protein-2 (Mrp2), Abcc2; and breast cancer resistance protein (Bcrp), Abcg2]. Dosing rats with SFN increased protein expression of all three transporters in brain capillaries and decreased by $50 \%$ brain accumulation of the P-glycoprotein substrate verapamil. Exposing rat or mouse brain capillaries to SFN increased P-glycoprotein, Bcrp, and Mrp2 transport activity and protein expression; SFN increased P-glycoprotein activity in mouse spinal cord capillaries. Inhibiting transcription or translation abolished upregulation of P-glycoprotein activity. No such effects were seen in brain capillaries from Nrf2-null mice, indicating Nrf2 dependence. Nrf2 signaled indirectly to increase transporter activity/expression. The p53 inhibitor pifithrin abolished the SFN-induced increase in transporter activity/expression, and the p53-activator nutlin-3 increased P-glycoprotein activity. SFN did not alter P-glycoprotein transport activity in brain and spinal cord capillaries from p53-null mice. Inhibitors of p38 MAPK and nuclear factor $\kappa \mathrm{B}(\mathrm{NF}-\kappa \mathrm{B})$ blocked the effects of SFN and nutlin-3 on P-glycoprotein activity. These results implicate Nrf2, p53, and NF- $\kappa$ B in the upregulation of P-glycoprotein, Bcrp, and Mrp2 at blood-CNS barriers. They imply that the barriers are tightened selectively (efflux transporter upregulation) by oxidative stress, providing increased neuroprotection, but also reduced penetration of many therapeutic drugs.

Key words: $\mathrm{ABC}$ transporters; blood-brain barrier; drug delivery; NF- $\kappa \mathrm{B} ;$ P-glycoprotein; p53

\section{Introduction}

Nuclear factor E2-related factor-2 (Nrf2) is a redox-sensitive, ligand-activated transcription factor that plays a critical role in cellular defenses against oxidative and electrophilic stress (Copple et al., 2010; Copple, 2012). In the absence of oxidants and electrophiles, Nrf2 is inactive and retained in the cytoplasm bound to Kelch-like ECH-associated protein 1 (Keap1). After oxidation of sulfhydryl groups on Keap1, Nrf2 is released and translocates to the nucleus, binding to antioxidant-response elements (AREs) in the promoter regions of target genes. Nrf2 drives expression of key players in the electrophile/antioxidant re-

Received July 10, 2013; revised May 2, 2014; accepted May 9, 2014.

Author contributions: X.W., R.E.C., and D.S.M. designed research; X.W., C.R.C., J.C.P., L.K.S., J.L.B., and R.E.C. performed research; X.W., C.R.C., R.E.C., and D.S.M. analyzed data; X.W., R.E.C., and D.S.M. wrote the paper.

This work was supported by the Intramural Research Program of the National Institute of Environmental Health Sciences, National Institutes of Health.

The authors declare no competing financial interests.

Correspondence should be addressed to David S. Miller, Laboratory of Toxicology and Pharmacology, National Institute of Environmental Health Sciences, National Institutes of Health, Research Triangle Park, NC 27709. E-mail: miller@niehs.nih.gov.

DOI:10.1523/JNEUROSCI.2935-13.2014

Copyright $\odot 2014$ the authors $\quad 0270-6474 / 14 / 348585-09 \$ 15.00 / 0$ sponse, including genes that code for proteins that produce GSH, reduce reactive oxygen species (ROS), and metabolize xenobiotics (Copple, 2012).

Administering Nrf2 ligands is neuroprotective in animal models of cerebral ischemia (Alfieri et al., 2011), traumatic brain injury (TBI) (Yan et al., 2008; Dash et al., 2009), subarachnoid hemorrhage (Chen et al., 2011; Z. Wang et al., 2012), and spinal cord injury (SCI; Mao et al., 2012; X. Wang et al., 2012). In a mouse model of TBI, postinjury administration of sulforaphane (SFN), an Nrf2 ligand found in cruciferous vegetables, protects the blood-brain barrier, increasing expression of cytoprotective genes and preserving barrier integrity (Dash et al., 2009). Thus, Nrf2 has been proposed as a therapeutic target in stroke, TBI, and SCI.

Although the major focus of research on Nrf2 targets has been on detoxifying/antioxidant enzymes, several ATP binding cassette $(\mathrm{ABC})$ transporters are Nrf2 targets. In barrier and excretory tissues, these transporters handle endogenous metabolites, xenobiotics (including therapeutic drugs), and xenobiotic metabolites. They contribute to xenobiotic defense mechanisms and are important determinants of xenobiotic uptake, distribution, and excretion. In hepatocytes, activating Nrf2 increases expression of multidrug resistance-associated protein 2 (Mrp2) to Mrp4 
(Abcc2-Abcc4) and possibly P-glycoprotein (Abcb1; Klaassen and Slitt, 2005; Maher et al., 2005; Aleksunes and Klaassen, 2012). Nrf2-null mice exhibit reduced hepatic expression of Mrp3 and Mrp4, and targeted deletion of Keap1 increases expression of Mrp1-Mrp5 and breast cancer resistance protein [Bcrp (Abcg2)].

The present study is concerned with the effects of Nrf2 activation on drug efflux transporters at the blood-brain and blood-spinal cord barriers. In both tissues, $\mathrm{ABC}$ transporters at the luminal, bloodfacing, surface of capillary endothelial cells drive outward transport and prevent potentially neurotoxic xenobiotics from entering the CNS. Thus, these transporters limit CNS accumulation of many therapeutic drugs (Miller, 2010; Campos et al., 2012). Of these transporters, P-glycoprotein handles the widest array of xenobiotics. Moreover, the large number of therapeutic drugs transported by P-glycoprotein makes this transporter a primary obstacle to CNS pharmacotherapy. Increased P-glycoprotein expression at brain barriers further limits delivery of therapeutic drugs to the CNS (Miller, 2010).

We show here that activation of Nrf2 at the blood-brain and blood-spinal cord barriers increased expression and transport function of P-glycoprotein, Mrp2, and Bcrp. These Nrf2-driven increases in transporter expression/activity required p53, p38, and nuclear factor $\kappa \mathrm{B}(\mathrm{NF}-\kappa \mathrm{B})$ to be active.

\section{Materials and Methods}

Materials. Mouse polyclonal P-glycoprotein antibody was obtained from Covance, and antibodies against MRP2 and BCRP were from Alexis Biochemicals. Heme oxygenase 1 (HO-1) antibody was purchased from Abcam. The fluorescent P-glycoprotein substrate [ $N$ - $\varepsilon$ (4-nitrobenzofurazan-7-yl)D-Lys ${ }^{8}$ cyclosporine A (NBD-CSA)] was custom-synthesized (Schramm et al., 1995). The fluorescent Mrp2 substrate sulforhodamine 101 free acid [Texas red (TR)] was purchased from Sigma-Aldrich, and the fluorescent Bcrp substrate BODIPY-prazosin was purchased from Life Technologies. PSC833 (3S, 6S, 9S, $12 R, 15 S, 18 S, 21 S, 24 S, 30 S, 33 S)-1,4,7,10,12,15,19$, 25,28-nonamethyl-33-[(E,2R)-2-methylhex-4-enoyl]-6,9,18,24-tetrakis (2-methylpropyl)-3,21,30-tri(propan-2-yl)-1,4,7,10,13,16,19,22,25,28, 31-undecazacyclotritriacontane-2,5,8,11,14,17,20,23,26,29,32-undecone), a specific inhibitor of P-glycoprotein, was kindly provided by Novartis. Mouse monoclonal $\beta$-actin antibody, Ficoll, SFN, tert-butylhydroquinone ( $t$ BHQ), and all other chemicals were obtained from Sigma-Aldrich. 2,3,7,8-Tetrachlorodibenzo- $p$-dioxin (TCDD) stock solution was prepared by RTI International. All reagents were of analytical grade or the best available pharmaceutical grade.

Animals. All experiments were performed in compliance with $\mathrm{Na}-$ tional Institutes of Health animal care and use guidelines and approved by the Animal Care and Use Committee of National Institute of Environmental Health Sciences (NIEHS). Male retired breeder Sprague Dawley rats (6-9 months; Taconic) were housed in temperature-controlled rooms under a $12 \mathrm{~h}$ light/dark cycle and were given ad libitum access to food and water. Nrf2 knock-out mice were provided by Dr. Steven Kleeberger at NIEHS; p53 knock-out mice were provided by Dr. Michael Fessler at NIEHS. Animals were killed by $\mathrm{CO}_{2}$ inhalation, followed by decapitation. Brain capillaries were isolated and immediately used for
B
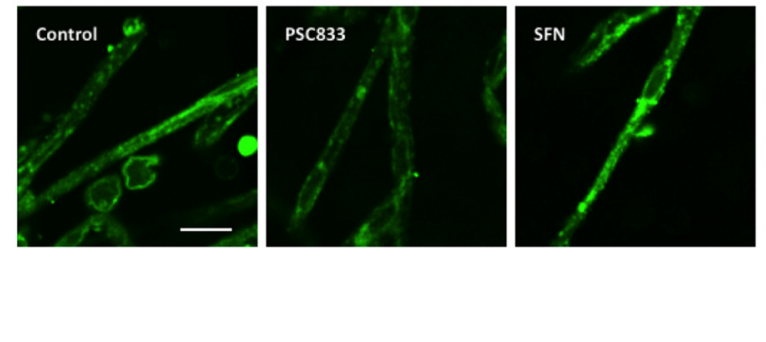

D
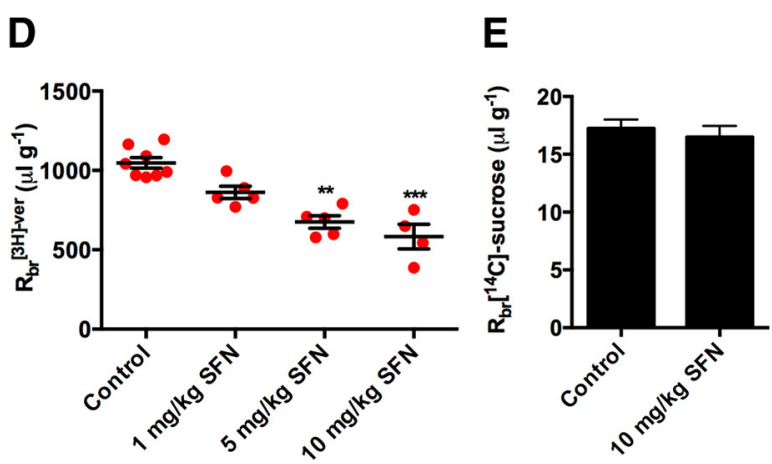
(scale bar, $10 \mu \mathrm{m})$. Capillaries were isolated from control and SFN-

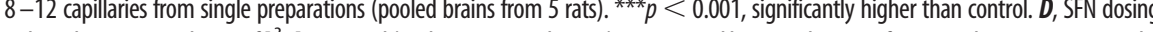
value for a single rat. ${ }^{* *} p<0.01$, significantly higher than control; ${ }^{* *} p<0.001$, significantly higher than control,
change brain accumulation of $\left[{ }^{14} \mathrm{C}\right]$ sucrose (tight junction permeability marker). Data are from five rats per group.

transport experiments; for Western blotting, capillary membranes were prepared and frozen for additional analysis.

Capillary isolation. Detailed procedures for capillary isolation were described previously (Miller et al., 2000; Hartz et al., 2004). Briefly, white matter, meninges, midbrain, choroid plexus, blood vessels, and olfactory lobes were removed from the brains under a dissecting microscope, and the brain tissue was homogenized. Tissue was kept in cold PBS (in mM: 2.7 KCl, $1.5 \mathrm{KH}_{2} \mathrm{PO}_{4}, 136.9 \mathrm{NaCl}, 8.1 \mathrm{Na}_{2} \mathrm{HPO}_{4}, 1 \mathrm{CaCl}_{2}, 0.5 \mathrm{MgCl}_{2}, 5$ $\mathrm{D}$-glucose, and 1 sodium pyruvate) throughout the isolation procedure. An aliquot of $30 \%$ Ficoll was added to an equal volume of brain homogenate, and capillaries were separated from the parenchyma by centrifuging at $5800 \times g$ for $20 \mathrm{~min}$. Capillary pellets were washed with $1 \% \mathrm{BSA}$ in PBS and passed through a syringe column filled with glass beads. Capillaries bound to the glass beads were released by gentle agitation, washed with PBS, and used immediately.

Transport assay. Confocal microscopy-based transport assays with isolated rat brain capillaries were described previously (Hartz et al., 2004). All experiments were performed at room temperature in coverslipbottomed imaging chambers filled with PBS. In general, rat or mouse brain capillaries were exposed to Nrf2 activator (SFN or $t \mathrm{BHQ}$ ) without or with additional inhibitors. Fluorescent substrates, NBD-CSA for P-glycoprotein, TR for Mrp2, and BODIPY-prazosin for Bcrp (Hartz et al., 2004; Bauer et al., 2008b; Wang et al., 2010), were added, and luminal substrate accumulation was assessed $1 \mathrm{~h}$ later. In each experiment, a specific transport inhibitor [MK571 (3-[[3-[(E)-2-(7-chloroquinolin-2-yl) ethenyl]phenyl]-[3-(dimethylamino)-3-oxopropyl]sulfanylmethyl] sulfanylpropanoate) for Mrp2 and Ko143 [tert-butyl 3-((3S,6S,12aS)-6isobutyl-9-methoxy-1,4-dioxo-1,2,3,4,6,7,12,12a-octahydropyrazino $\left[1^{\prime}, 2^{\prime}\right.$ : 1,6]pyrido[3,4-b]indol-3-yl)propanoate] for Bcrp] was used to define the mediated component of luminal substrate accumulation (see Re- 
A

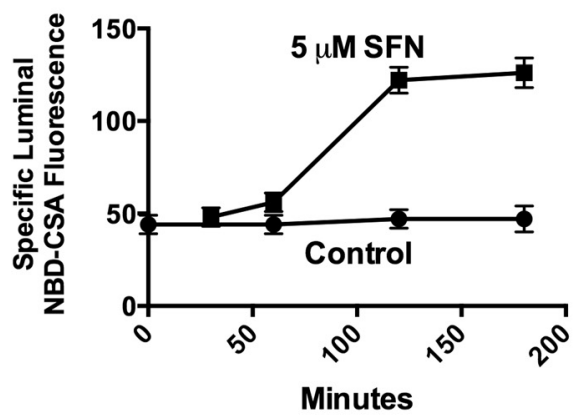

B

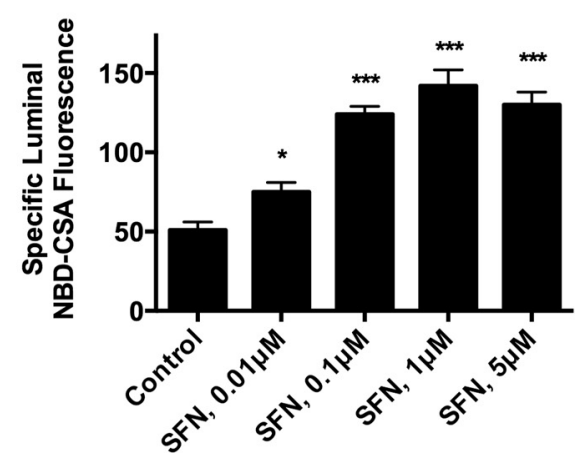

C

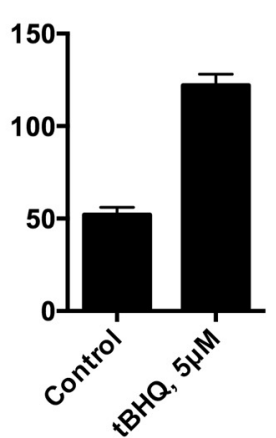

D

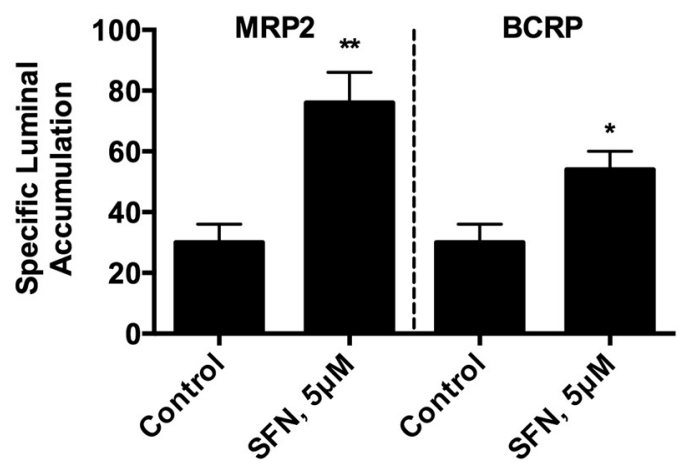

Figure 2. Effects of SFN exposure on $A B C$ transporter transport activity in isolated rat brain capillaries (specific luminal accumulation of transporter-selective fluorescent drugs; see Results). $\boldsymbol{A}$, Time course of SFN-induced increase of P-glycoprotein transport activity. Capillaries were incubated in medium with $5 \mu \mathrm{m}$ SFN for the time shown and then incubated for 1 additional hour with SFN and $2 \mu \mathrm{M}$ NBD-CSA. B, SFN dose response for P-glycoprotein activity. The exposure time is $4 \mathrm{~h}$ ( $3 \mathrm{~h}$ with SFN plus $1 \mathrm{~h}$ with SFN and $2 \mu \mathrm{M}$ NBD-CSA). C, Increased P-glycoprotein transport activity in brain capillaries exposed to $t B H Q$. D, SFN exposure increases Mrp2 and Bcrp transport activity in brain capillaries. Shown are mean \pm SEM for 10-15 capillaries from single preparations (pooled brains from $8-10$ rats). ${ }^{*} p<0.05,{ }^{* *} p<0.01,{ }^{* * *} p<0.001$, significantly higher than control.
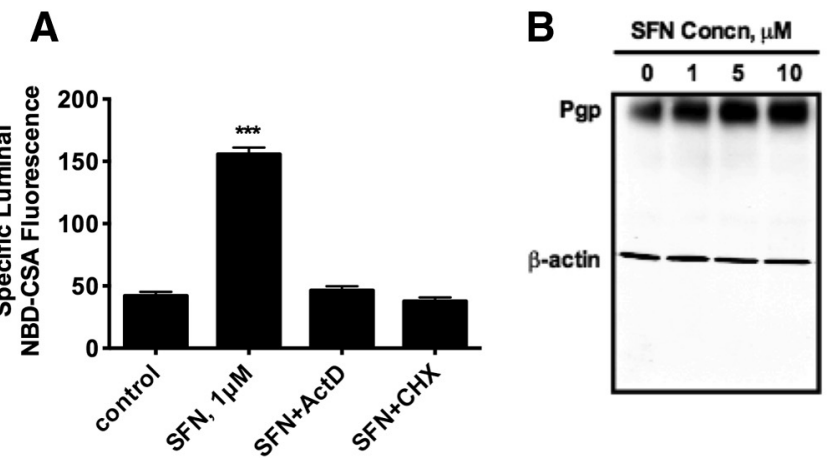

Figure 3. The SFN-induced increase in P-glycoprotein activity requires transcription and translation (rat brain capillaries). $\boldsymbol{A}$, Inhibition of transcription [1 $\mu \mathrm{m}$ actinomycin D (ActD)] or translation $[100 \mu \mathrm{g} / \mathrm{mL}$ cycloheximide (CHX)] abolishes the increase in transport activity caused by exposure to $5 \mu \mathrm{m}$ SFN. Shown are mean \pm SEM for 8-12 capillaries from a single preparation (pooled brains from 10 rats). ${ }^{* * *} p<0.001$, significantly higher than control. $\boldsymbol{B}, \boldsymbol{C}$, Western blots of brain capillary membranes showing that $4 \mathrm{~h}$ exposure of capillaries to SFN exposure increases P-glycoprotein (Pgp) expression in a concentration-dependent manner.

sults). To acquire images, the chamber containing the capillaries was mounted on the stage of a Zeiss model 510 inverted confocal laser scanning microscope and imaged through a $40 \times$ water-immersion objective (numeric aperture 1.2) using a $488 \mathrm{~nm}$ laser line for NBD-CSA and BODIPY-prazosin and a $543 \mathrm{~nm}$ laser line for TR. Images were saved to disk, and luminal fluorescence was quantitated by NIH ImageJ software as described previously (Miller et al., 2000). Data shown are for a single experiment that is representative of three to five replicates.

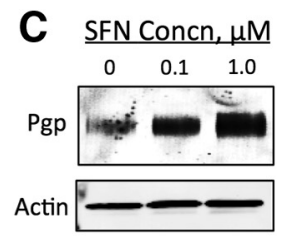

Western blots. Membranes were isolated from control and SFN-exposed capillaries as described previously (Hartz et al., 2004; Bauer et al., 2006). Membrane protein was assayed by the Bradford method. An aliquot of the membrane protein was mixed with NuPAGE $4 \times$ sample buffer (Invitrogen), loaded onto 4-12\% Bis-Tris NuPAGE gel, electrophoresed, and then transferred to an Immobilon-FL membrane (Millipore). The membrane was blocked with Odyssey Blocking Buffer (Li-Cor Biosciences) at room temperature for $1 \mathrm{~h}$ and then immunoblotted with antibodies against P-glycoprotein. The membrane was stained with corresponding goat anti-mouse fluorescence dye IRDye 800 in PBS with $0.1 \%$ Tween 20 at room temperature for $45 \mathrm{~min}$ and then imaged using an Odyssey Infrared Imaging System (Li-Cor Biosciences). $\beta$-Actin ( $42 \mathrm{kDa}$; 1:2000) was used as a loading control.

Electrophoresis mobility shift assay. Nuclear protein extract was isolated from control and SFN-induced brain capillaries using an NE-PER kit (Pierce) and by following the instructions of the manufacturer. cDNA oligonucleotides [5' CTA ATG GTG ACA AAG CAA CTT T- $3^{\prime}$ and 5'-AAA GTT GCT TTG TCA CCA TTA G-3' (ARE recognition sequence in bold); 5'-TAC AGA ACA TGT CTA AGC ATG CTG GGG ACT- $3^{\prime}$ and $5^{\prime}$-AGT CCC CAG CAT GCT TAG ACA TGT TCT GTA-3' (p53); and 5'AGT TGA GGG GAC TTT CCC AGG C- $3^{\prime}$ and G CCT GGG AAA GTC CCC TCA ACT-3' $(\mathrm{NF}-\kappa \mathrm{B})]$ were end labeled with IRDye680 fluorescent dyes by IDT and annealed at $100^{\circ} \mathrm{C}$ for 5 min (B. Zhao et al., 2006; Wang et al., 2011). The electrophoresis mobility shift assay (EMSA) samples were prepared using Odyssey Infrared EMSA Buffer kit (Li-Cor Biosciences), with $5 \mu \mathrm{g}$ of nuclear protein extract used in each Nrf2/ARE binding reaction. The binding reaction was incubated at room temperature for $20 \mathrm{~min}$, and the DNA-protein complexes were resolved on a precast, $6 \%$ native polyacrylamide gel in $0.5 \times$ Tris Borate EDTA buffer. The gel was removed from the electrophoresis unit and directly imaged on the Odyssey Infrared Imaging System.

Immunostaining for $N F-\kappa B$. Isolated brain capillaries were exposed to SFN and other chemicals, fixed, permeabilized, and incubated with primary (rabbit polyclonal ab 16502; Abcam) and secondary [goat anti-rabbit IgG $(\mathrm{H}+\mathrm{L})$ Alexa Fluor 488; A11008; Life Technologies] antibodies as described previously (Wang et al., 2010). The primary antibody used recognizes p65, which translocates into the nucleus during NF- $\kappa \mathrm{B}$ activation. Immunostained capillaries were imaged with a Zeiss model 510 inverted confocal laser scanning microscope and imaged through a $40 \times$ water-immersion objective (numeric aperture 1.2) using a $488 \mathrm{~nm}$ laser line. Images were saved to disk, and nuclear fluorescence was quantitated using NIH ImageJ software.

In situ brain perfusion. Brain perfusion was performed as described previously (Hawkins et al., 2010). Rats were anesthetized by intraperitoneal injection with $1 \mathrm{ml} / \mathrm{kg}$ ketamine mixture (in mg/ml: 79 ketamine, 3 zylazine, and 0.6 acepromazine) and administered heparin $(10 \mathrm{kU} / \mathrm{kg})$. The common carotid arteries were exposed by midline incision at the 
neck and perfused with oxygenated Ringer's solution at $37^{\circ} \mathrm{C}(117 \mathrm{~mm}$

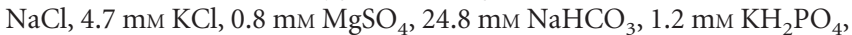
$2.5 \mathrm{~mm} \mathrm{CaCl}_{2}, 10 \mathrm{~mm}$ D-glucose, $39 \mathrm{~g} / \mathrm{L} 170 \mathrm{kDa}$ dextran, and $1 \mathrm{~g} / \mathrm{L} \mathrm{BSA}$ ) at $3 \mathrm{ml} / \mathrm{min}$. $\left[{ }^{14} \mathrm{C}\right]$ Sucrose $(0.5 \mu \mathrm{Ci} / \mathrm{ml})$ or $\left[{ }^{3} \mathrm{H}\right]$ verapamil $(0.1 \mu \mathrm{Ci} / \mathrm{ml})$ were infused into the circuit via syringe pump at $0.5 \mathrm{ml} / \mathrm{min}$ for $20 \mathrm{~min}$. Samples of perfusate were collected from the cannulae at the end of each experiment. Brains were removed, stripped of meninges, midbrain, and choroid plexuses, and minced. Tissue and $100 \mu$ l perfusate samples were solubilized and counted (Hawkins et al., 2010). Results were expressed as the ratio of disintegrations per minutes in the brain/disintegrations per minutes in the perfusate (shown as $R_{\mathrm{br}} \mu \mathrm{l} / \mathrm{g}$ ).

Statistical analyses. Data are expressed as mean \pm SEM. Statistical analyses of differences between groups was by one-way ANOVA (Newman-Keuls multiple comparison test) using Prism 5.0 software. Differences between two means were considered significant when $p<0.05$.

\section{Results}

SFN upregulates $\mathrm{ABC}$ transporter expression in vivo

We dosed rats by intraperitoneal injection with $10 \mathrm{mg} / \mathrm{kg} \mathrm{SFN}$ for $2 \mathrm{~d}$ and, on day 3 , isolated brain capillaries for subsequent determination of ABC transporter expression and P-glycoprotein transport activity. Previous studies showed that this dosing protocol induces Nrf2 target enzymes in mouse brain and is neuroprotective in mice after ischemic stroke (J. Zhao et al., 2006). Figure $1 A$ shows increased P-glycoprotein, Mrp2, and BCRP protein expression in brain capillaries from SFN-dosed rats. SFN dosing also increased expression of HO-1, a known Nrf2 target.

To assess transporter function, we assayed transport activity in brain capillaries isolated from control and SFN-dosed rats. Our laboratory established a method to measure the transport activity of ATP-driven efflux transporters in freshly isolated brain and spinal cord capillaries using fluorescent substrates, transporter-specific inhibitors, confocal microscopy, and digital image analysis (Hartz et al., 2004). For P-glycoprotein, specific transport activity is measured as PSC833-sensitive NBD-CSA accumulation in capillary lumens at steady state $(60 \mathrm{~min}$; Wang et al., 2010). Figure $1 B$ shows representative confocal images of rat brain capillaries incubated to steady state in medium with $2 \mu \mathrm{M}$ NBD-CSA without (control) and with $5 \mu \mathrm{M}$ PSC833. Note the accumulation of fluorescence in the lumen of the control capillary and the substantial reduction $(60-70 \%)$ in luminal fluorescence in the capillary exposed to $5 \mu \mathrm{M}$ PSC833 (Fig. 1B). This concentration of inhibitor maximally reduces luminal NBD-CSA accumulation. Previous studies showed that luminal fluorescence remaining after PSC833 inhibition of NBD-CSA transport represents nonspecific accumulation, likely from diffusive entry and binding to cellular elements (Hartz et al., 2004). Recent experiments show that luminal NBD-CSA accumulation in brain and spinal cord capillaries from P-glycoprotein-null mice was the same as in capillaries from wild-type mice that were exposed to $5 \mu \mathrm{M}$ PSC833 (Campos et al., 2012). For the present experiments using NBD-CSA as a P-glycoprotein substrate, results are expressed as PSC833-sensitive luminal fluorescence, which we take as a measure of specific P-glycoprotein transport activity. Figure $1 B$ also shows increased NBD-CSA luminal fluorescence in brain capillaries isolated from rats that were dosed with $10 \mathrm{mg} / \mathrm{kg}$ SFN. Quantification of specific luminal fluorescence showed that P-glycoprotein transport activity was $150 \%$ higher than in brain capillaries from SFN-dosed rats than in capillaries from control rats (Fig. 1C).

We used in situ brain perfusion to measure the accumulation of $\left[{ }^{3} \mathrm{H}\right]$ verapamil in brains of control and SFN-dosed rats $(1-10$ $\mathrm{mg} / \mathrm{kg}$ SFN for $2 \mathrm{~d}$ ). We used altered $\left[{ }^{3} \mathrm{H}\right]$ verapamil accumulation in brain as a sensitive measure of changes in P-glycoprotein activity at the blood-brain barrier, with uptake decreasing with
A

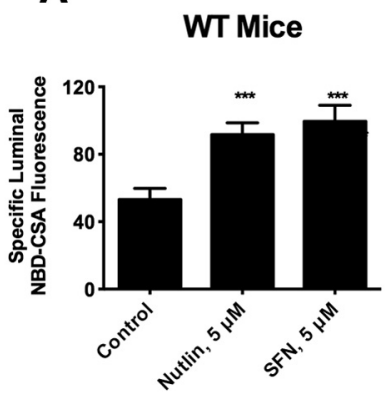

C

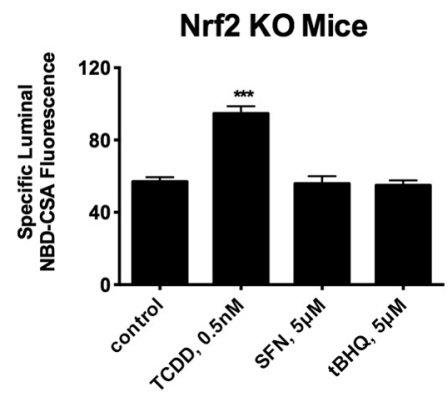

B

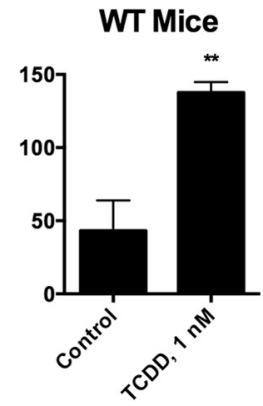

D

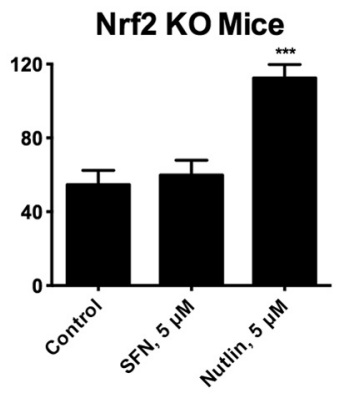

Figure 4. Effects of Nrf2 (SFN) and AhR (TCDD) ligands and p53 activation (nutlin-3) on P-glycoprotein transport activity in brain capillaries from wild-type $(\boldsymbol{A}, \boldsymbol{B})$ and $\operatorname{Nrf2-null}(\boldsymbol{C}, \boldsymbol{D})$ mice. Shown are mean \pm SEM for 8-12 capillaries from single preparations (pooled brains from 10 mice). ${ }^{* *} p<0.01,{ }^{* *} p<0.001$, significantly higher than control.

increased transporter activity and increasing with decreased activity (Wang et al., 2011; Cannon et al., 2012). As shown in Figure $1 D$, SFN dosing reduced brain $\left[{ }^{3} \mathrm{H}\right]$ verapamil accumulation in a dose-dependent manner. With 5 or $10 \mathrm{mg} / \mathrm{kg} \mathrm{SFN}$, accumulation decreased significantly, with $10 \mathrm{mg} / \mathrm{kg}$ reducing accumulation by $\sim 50 \%$. SFN had no effect on brain accumulation of $\left[{ }^{14} \mathrm{C}\right] \mathrm{su}-$ crose, a sensitive measure of tight junction permeability (Fig. 1E). Thus, dosing rats with SFN increased blood-brain barrier expression of P-glycoprotein, Mrp2, and Bcrp, increased P-glycoprotein transport activity in isolated brain capillaries and reduced brain accumulation of a P-glycoprotein substrate.

\section{SFN activation upregulates $\mathrm{ABC}$ transporters in vitro}

To define the mechanism by which SFN alters activity and expression of $\mathrm{ABC}$ transporters at the blood-brain barrier, we examined SFN effects in isolated rat and mouse brain capillaries. We first exposed rat brain capillaries to $5 \mu \mathrm{M}$ SFN for $1-4 \mathrm{~h}$ and then incubated them to steady state ( 1 additional hour) in medium with $2 \mu \mathrm{M}$ NBD-CSA plus SFN. Figure $2 A$ shows that SFN exposure increased specific luminal accumulation of NBS-CSA over 1-4 h. After 2-3 h of SFN exposure, P-glycoprotein transport activity had approximately tripled. For the remainder of the experiments presented here, capillaries were exposed for $3 \mathrm{~h}$ to ligands for Nrf2 and other ligand-activated transcription factors before fluorescent substrate was added to the medium for the 60 min transport assay (total exposure time, $4 \mathrm{~h}$ ).

Exposing rat brain capillaries to SFN increased P-glycoprotein transport activity in a concentration-dependent manner, with concentrations as low as $0.01 \mu \mathrm{M}$ SFN causing a significant increase and 1-5 $\mu \mathrm{M}$ SFN causing a maximal increase (Fig. $2 B$ ). With 1 or $5 \mu \mathrm{M}$ SFN, transport activity was approximately three times that seen in control capillaries. Exposure to another Nrf2 ligand, $t \mathrm{BHQ}$, increased transport activity to the same extent 
A

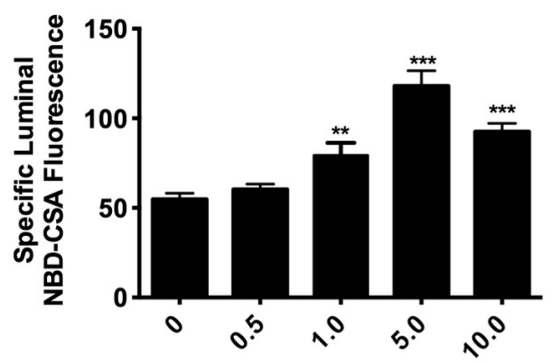

Nutlin Concn, $\mu \mathrm{M}$
B

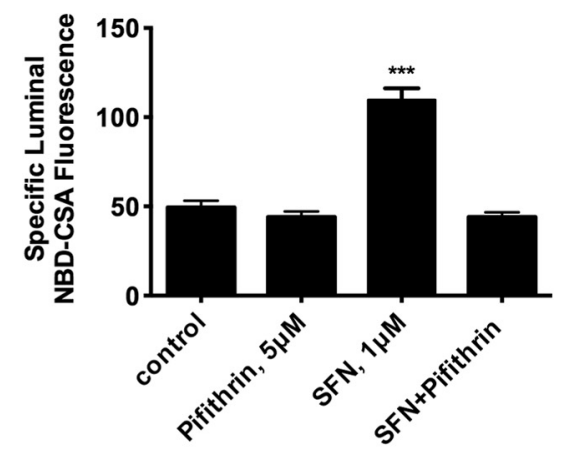

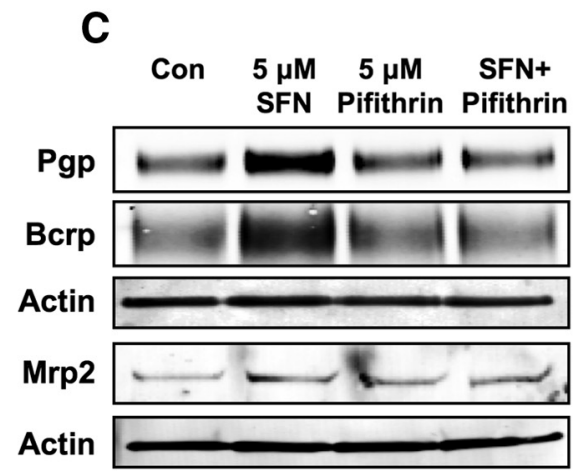

Figure 5. Involvement of p53 in SFN induction of $\mathrm{ABC}$ transporter expression and activity in rat brain capillaries. $A$, Nutlin-3, a p53 activator, increases P-glycoprotein activity in a concentration-dependent manner. $\boldsymbol{B}$, Pifithrin, a p53 inhibitor, blocks the SFN-induced increase in P-glycoprotein activity. Shown are mean \pm SEM for 8-12 capillaries from single preparations (pooled brains from 10 rats). ${ }^{* *} p<0.01,{ }^{* * *} p<0.001$, significantly higher than control. C, Western blots showing increased P-glycoprotein (Pgp), Bcrp, and Mrp2 expression in membranes from SFN-exposed capillaries. The increase in transporter expression is abolished when $\mathrm{p} 53$ is inhibited by pifithrin; pooled capillary membranes from 10 rats. Con, Control.

A

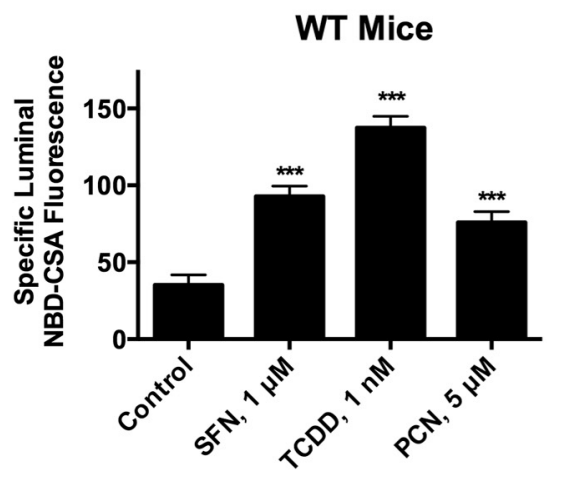

B

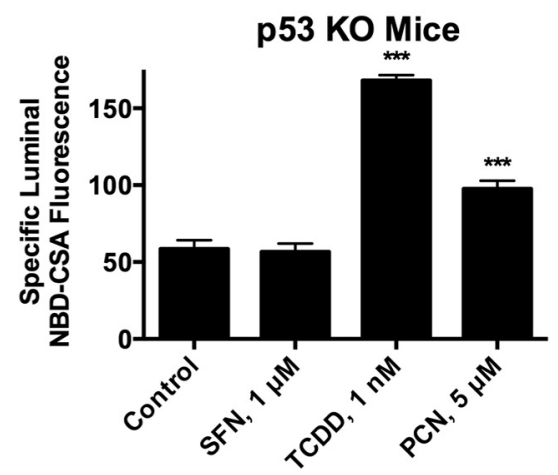

Figure 6. Effects of Nrf2 (SFN), AhR (TCDD), and PXR (PCN) ligands on P-glycoprotein transport activity in brain capillaries from wild-type $(\boldsymbol{A})$ and p53-null $(\boldsymbol{B})$ mice. Shown are mean \pm SEM for 8-12 capillaries from single preparations (pooled brains from 10 mice). ${ }^{* * *} p<0.001$, significantly higher than control.

as SFN (Fig. 2C). We also measured the effects of SFN exposure on the transport activity of two other $\mathrm{ABC}$ transporters, Mrp2 and Bcrp. Again, we used a confocal microscopy-based assay to measure accumulation of fluorescent substrates (TR for Mrp2 and BODIPY-prazosin for Bcrp) within rat brain capillary lumens; specific inhibitors used were MK571 for Mrp2 and Ko143 for Bcrp (Hartz et al., 2004; Bauer et al., 2008b; Wang et al., 2010). Figure $2 D$ shows that $5 \mu$ M SFN significantly increased Mrp2 and Bcrp transport activity in brain capillaries.
The increase in P-glycoprotein transport activity caused by SFN exposure in brain capillaries was abolished by actinomycin D and cyclohexamide, indicating dependence on transcription and translation (Fig. $3 A$ ). We showed previously that neither actinomycin $\mathrm{D}$ nor cyclohexamide affected P-glycoprotein transport in brain capillaries (Wang et al., 2010). Consistent with translation of new transporter protein, Western blots of capillaries exposed to 0.1-10 $\mu \mathrm{M}$ SFN showed concentration-dependent increases in P-glycoprotein expression (Figs. $3 B, C$; expression data for Mrp2 and Bcrp in SFN-exposed capillaries are shown below).

No specific antagonist has been identified for Nrf2. To confirm the role of Nrf2 in the modulation of P-glycoprotein transport and expression, we isolated brain capillaries from wild-type (C57BL/6) and $\mathrm{Nrf} 2$ knock-out (C57BL/6 background) mice and exposed them to Nrf2 activators. In the capillaries from wild-type mice, $5 \mu \mathrm{M}$ SFN significantly increased P-glycoprotein transport activity (Fig. 4A). In capillaries from Nrf2-null mice, neither SFN nor $t$ BHQ increased transport activity (Fig. $4 B)$. In capillaries from wild-type and Nrf2-null mice, P-glycoprotein transport activity was clearly inducible, because TCDD, an aryl hydrocarbon receptor (AhR) ligand, and nutlin-3, an activator of tumor suppressor p53, significantly increased transport activity (Fig. $4 B-D$ ). The TCDD effect is in agreement with our previous reports, showing that exposing rat brain capillaries to this AhR ligand upregulated P-glycoprotein transport (Wang et al., 2011). The nutlin-3 effect is novel and is investigated in detail below.

\section{Nrf2 signals through p53 and p38 MAPK}

p53 is a tumor suppressor that affects cell fate decisions, including cell cycle arrest, apoptosis, differentiation, and stress resistance (Chen et al., 2012; Rotblat et al., 2012). The relationship between $p 53$ and oxidative stress is complex, with p53 acting as a redox-sensitive transcription factor that can generate antioxidant or pro-oxidant responses (Vurusaner et al., 2012). Our initial experiments with mouse brain capillaries indicated that activation of $\mathrm{p} 53$ by nutlin- 3 increased P-glycoprotein transport activity (Fig. $4 A$ ). Additional experiments with rat brain capillaries showed that exposure to $1-10 \mu \mathrm{M}$ nutlin-3 for $3 \mathrm{~h}$ increased P-glycoprotein transport activity in a concentrationdependent manner (Fig. 5A). We used three strategies to determine whether p53 was involved in Nrf2 signaling to $\mathrm{ABC}$ transporters. First, we pretreated rat brain capillaries with $5 \mu \mathrm{m}$ pifithrin, a reversible inhibitor of p53-dependent gene transcription, and then exposed them to $1 \mu \mathrm{M}$ SFN. Pifithrin blocked the ability of SFN to 
increase P-glycoprotein transport activity (Fig. 5B). Second, we pretreated rat brain capillaries with pifithrin, exposed them to 5 $\mu \mathrm{M}$ SFN for $3 \mathrm{~h}$, and analyzed ABC transporter expression in capillary membranes by Western blots. Figure $5 C$ shows clearly that SFN increased expression of P-glycoprotein and Bcrp and possibly Mrp2; pifithrin blocked the increases in protein expression.

Third, we isolated brain capillaries from wild-type (C57BL/6) and p53-null mice and measured changes in P-glycoprotein transport activity after exposure to SFN, TCDD (AhR ligand), and pregnenolone $16 \alpha-$ carbonitrile [PCN; pregnane $\mathrm{X}$ receptor (PXR) ligand]. We showed previously that ligand activation of AhR and PXR increases P-glycoprotein transport activity and protein expression in rodent brain capillaries (Bauer et al., 2004; Wang et al., 2011). Figure $6 A$ shows that, in capillaries from wild-type mice, all three ligands increased P-glycoprotein transport activity. Although transport activity in capillaries from p53-null mice increased with exposure to TCDD and PCN, no such increase was seen with exposure to SFN (Fig. 6B). Thus, functional p53 is required for Nrf2 to upregulate P-glycoprotein, Mrp2, and Bcrp at the bloodbrain barrier.

To further map the chain of events connecting Nrf2 activation to increased P-glycoprotein function, we tested whether specific inhibitors of protein kinase signaling blocked the ability of SFN to increase P-glycoprotein transport activity in rat brain capillaries. Pretreating capillaries with inhibitors of MEK [U0126 (1,4-diamino-2,3-dicyano-1,4-bis(o-aminophenylmercapto) butadiene)] or phosphatidylinositol 3-kinase/Akt (wortmannin), did not affect SFN action (data not shown). In contrast, pretreatment with a specific p38 MAPK inhibitor, SB203580 [4-(4-fluorophenyl)-2(4-methylsulfinylphenyl)-5-(4-pyridyl)-1 $H$-imidazole], abolished the effect of SFN on P-glycoprotein transport (Fig. 7A). Preliminary experiments with another $\mathrm{p} 38 \mathrm{MAPK}$ inhibitor confirm this finding (data not shown). These findings are consistent with a previous report showing that Nrf2 signals through p38 MAPK to increase HO-1 expression (Paine et al., 2010). To determine whether p38 MAPK signaling was downstream of p53 in the Nrf2 pathway, we exposed rat brain capillaries to both nutlin-3 and SB203580. As shown in Figure 7B, SB203580 abolished the effect of nutlin-3 on transport, indicating that p38 MAPK was downstream of $\mathrm{p} 53$.

\section{Signaling through NF- $\kappa \mathrm{B}$}

$\mathrm{NF}-\kappa \mathrm{B}$ is a transcription factor that was implicated in responses to a number of cellular stressors, including inflammatory, genotoxic, and oxidative stress. In rat brain capillaries, inhibition of $\mathrm{NF}-\kappa \mathrm{B}$ abolishes the increases in P-glycoprotein activity and protein expression caused by exposure to TNF- $\alpha$ and excess glutamate (Bauer et al., 2004, 2008a). Here, we used N4-[2-(4phenoxyphenyl)ethyl]-4, 6-quinazolinediamine (QNZ), an NF- $\kappa \mathrm{B}$ inhibitor that blocks activation, and SN50, a cell-permeable peptide
B

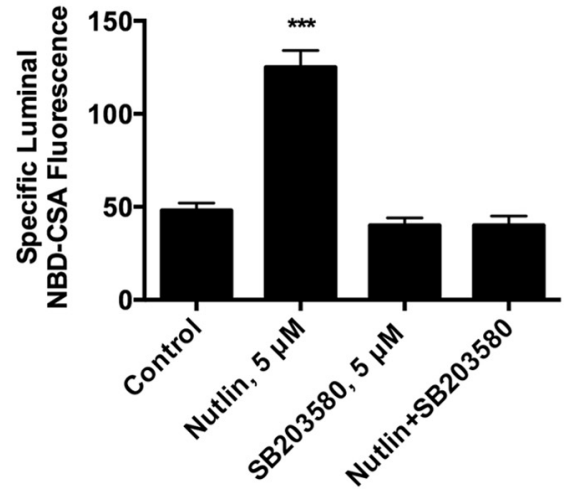

Figure 7. Effects of a p38 MAPK inhibitor (SB203580) on the increase in P-glycoprotein transport activity caused by exposure to SFN $(\boldsymbol{A})$ and nutlin-3 $(\boldsymbol{B})$. Shown are mean \pm SEM for 10-12 capillaries from single preparations (pooled brains from 6 rats).

A

Figure 8. $\quad A, A n N F-\kappa B$ inhibitor (QNZ) blocks the increases in P-glycoprotein transport activity caused by exposure to SFN and nutlin-3. $B$, A second NF- $\kappa$ B inhibitor (SN50) blocks the increases in P-glycoprotein transport activity caused by exposure to SFN. Shown are mean \pm SEM for 8-12 capillaries from single preparations (pooled brains from 6 rats). ${ }^{* * *} p<0.001$, significantly higher than control.

inhibitor that blocks nuclear translocation, to determine whether $\mathrm{NF}-\kappa \mathrm{B}$ was involved in Nrf2- and p53-driven increases in $\mathrm{P}$-glycoprotein activity in rat brain capillaries. As shown in Figure 8, $A$ and $B$, QNZ abolished the effects of SFN and nutlin-3 on transport activity; SN50 abolished the effects of SFN on transport activity.

EMSA provides a means of determining whether specific transcription factors move into the nucleus and are capable of binding to added DNA probes encoding consensus promoter binding sites for the proteins. We exposed rat brain capillaries to $5 \mu \mathrm{M}$ $\mathrm{SFN}$, isolated rat brain capillary nuclear proteins, and measured binding of Nrf2, p53, and NF- $\kappa \mathrm{B}$ to cognate fluorescent DNA probes. In each case, SFN exposure of capillaries increased probe mass in gels, indicative of transcription factor binding to the probe (Figure 9A). Thus, in brain capillaries, SFN exposure results in nuclear translocation of Nrf2, p53, and NF- $\kappa \mathrm{B}$.

We immunostained isolated rat brain capillaries to confirm SFNinduced, nuclear translocation of the NF- $\kappa \mathrm{B}$ component $\mathrm{p} 65$, a measure of NF- $\kappa$ B activation. Figure $9 B$ shows representative transmitted light and confocal fluorescence images of capillaries immunostained for $\mathrm{p} 65$. The white arrows indicate nuclei for which fluorescence intensity profiles were measured. In this experiment, capillaries were fixed after $30 \mathrm{~min}$ exposure to $5 \mu \mathrm{M}$ SFN without and with inhibitors (20 nM QNZ or $10 \mu \mathrm{M}$ SN50). Preliminary experiments showed that nuclear fluorescence intensity increased maximally at that time. Note first that individual pixel fluorescence intensities across the representative nucleus from the SFN-exposed 
A
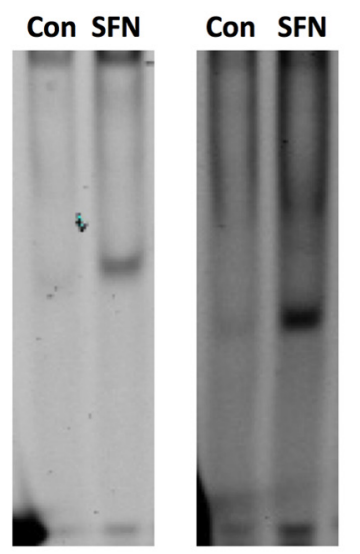

p53
B
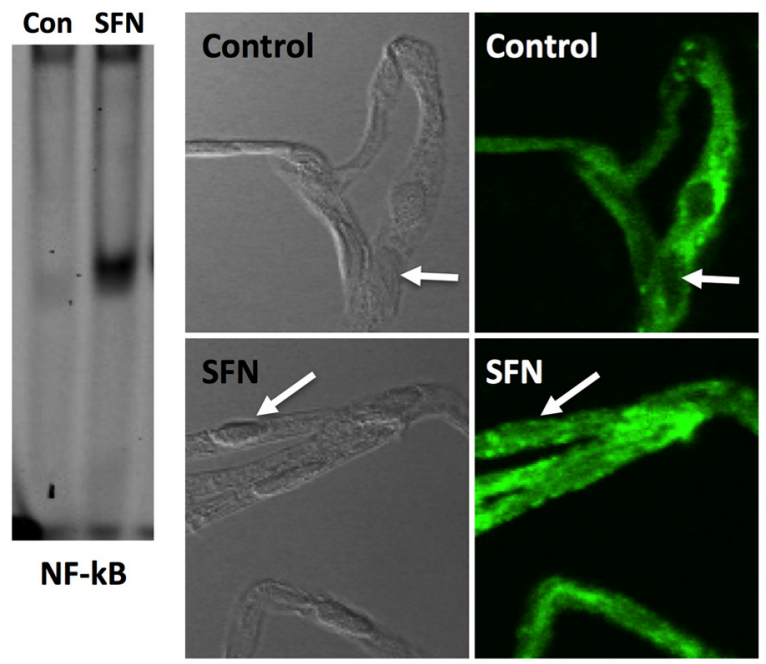

C
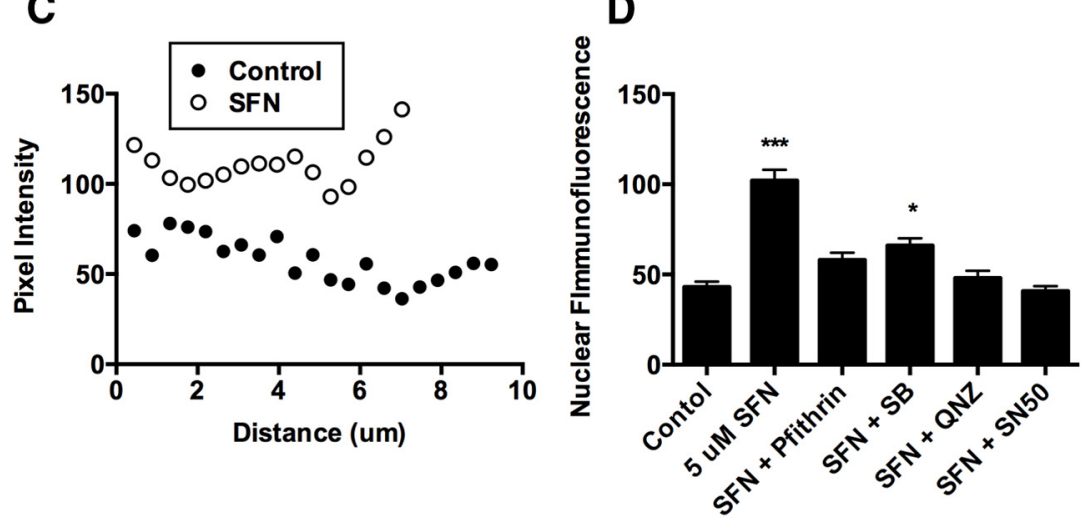

E

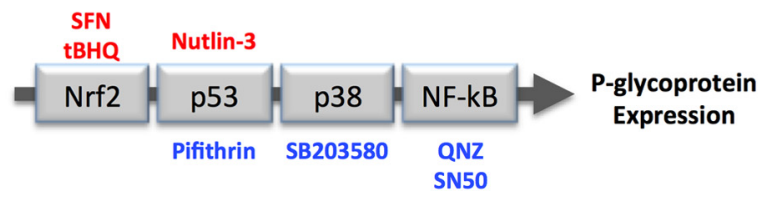

Figure 9. $A$, EMSAs show nuclear translocation of Nrf2, $\mathrm{p} 53$, and NF- $\kappa \mathrm{B}$ in response to exposure of rat brain capillaries to $5 \mu \mathrm{M}$ SFN for $4 \mathrm{~h}$. Con, Control. $\boldsymbol{B}$, Immunostaining for p65 shows nuclear translocation of NF- $\kappa$ B after 30 min exposure to $5 \mu \mathrm{m}$ SFN. Arrows indicate nuclei selected for pixel intensity profile analysis. C, Pixel intensity profiles for immunostained (p65) nuclei in control and SFN-exposed capillaries. There is no overlap in the intensity profiles. $\boldsymbol{D}$, Mean nuclear pixel intensities in immunostained (p65) capillaries. SFN exposure more than doubles pixel intensity and inhibitors of p53, p38, and NF- $\kappa$ B activation and translocation essentially block this increase. Shown are mean \pm SEM for 40-60 nuclei (15-25 capillaries) from two capillary preparations. ${ }^{*} p<0.05,{ }^{* * *} p<0.001$, significantly higher than control. $\boldsymbol{E}$, The sequence of events through which Nrf2 ligands increase $\mathrm{P}$-glycoprotein expression. Activators are shown in red, and inhibitors are in blue.

capillary were higher than in the nucleus from the control capillary (Fig. 9C). Measurements of average nuclear fluorescence intensities showed at least a doubling after SFN exposure (Fig. 9D). Importantly, both NF- $\kappa$ B inhibitors, QNZ and SN50, blocked this increase, as did inhibitors of p53 (pifithrin) and p38 (SB203580; Fig. 9D).

Together, our findings for isolated brain capillaries show that $\mathrm{Nrf2}$ requires $\mathrm{p} 53, \mathrm{p} 38$, and $\mathrm{NF}-\kappa \mathrm{B}$ to upregulate $\mathrm{ABC}$ transporter expression at the blood-brain barrier. They also indicate that NF- $\kappa \mathrm{B}$ is essential for upregulation of transport activity when p53 is activated independently of Nrf2. These results define a sequence of events leading to increased transporter expression in rodent brain capillaries exposed to SFN (Fig. 9E).
Nrf2 signaling in spinal cord capillaries We demonstrated recently that $\mathrm{ABC}$ transporter function and regulation could be studied in spinal cord capillaries isolated from rats and mice using the same procedures as with brain capillaries (Campos et al., 2012). As in brain capillaries, we used PSC833-dependent steady-state luminal accumulation of NBD-CSA as a measure of specific $\mathrm{P}$-glycoprotein transport activity in spinal cord capillaries. Figure $10 \mathrm{~A}$ shows that exposing spinal cord capillaries from wild-type mice to $5 \mu \mathrm{M}$ SFN, $1 \mathrm{nM}$ TCDD, or $5 \mu \mathrm{M}$ PCN for $3 \mathrm{~h}$ nearly doubled transport activity. The TCDD and PXR results confirm previous findings in rat spinal cord capillaries (Campos et al., 2012). The SFN result indicates that, as in brain capillaries (above), activation of Nrf2 increased P-glycoprotein transport activity. In spinal cord capillaries from p53-null mice, exposure to TCDD and PCN increased transport activity, but SFN had no effect (Fig. $10 B$ ). Thus, as with brain capillaries from rats and mice (see above), SFN increased $\mathrm{P}$-glycoprotein transport activity in mouse spinal cord capillaries, and those increases were p53 dependent.

\section{Discussion}

Together, Nrf2 and its cytoplasmic partner Keap1 function as a redox/electrophile sensor, driving a concerted cellular response to oxidative and electrophilic stress. Activation of $\mathrm{Nrf} 2$ is protective in a number of animal models of tissue injury, including ozone and arsenic toxicity in lung, acetaminophen hepatotoxicity, and diabetic nephropathy (Aleksunes and Manautou, 2007; Cho and Kleeberger, 2007; Li et al., 2012). In the CNS, preconditioning with Nrf2 ligands is neuroprotective in animal models of cerebral ischemia, TBI, subarachnoid hemorrhage, and SCI. Several reports suggest the use of Nrf2 ligands that are dietary constituents, e.g., SFN and curcumin, as therapeutic interventions in patients at risk for stroke and possibly as a treatment after cerebral ischemia, TBI, subarachnoid hemorrhage, and SCI (Yan et al., 2008; Dash et al., 2009; Alfieri et al., 2011; Chen et al., 2011; Mao et al., 2012; X. Wang et al., 2012; Wang et al., 2013). Recent phase 3 clinical trials show that dimethyl fumarate, an Nrf2 ligand (Linker et al., 2011), reduced relapse rates and improved neuroradiologic outcomes in patients with relapsing-remitting multiple sclerosis (Fox et al., 2012; Gold et al., 2012). Given the potential for Nrf2 activation during treatment of CNS disease, it is important to understand the full range of consequences.

Limited information for peripheral tissues indicates that upregulation of xenobiotic efflux transporter expression is part of the Nrf2 response, e.g., in liver, multiple Mrps are Nrf2 targets (Klaassen and Slitt, 2005; Maher et al., 2005; Aleksunes and Klaassen, 2012). In the present study, we show that activation of $\mathrm{Nrf} 2$ at the rat and mouse 
blood-brain barriers increased protein expression of P-glycoprotein, Bcrp, and Mrp2, three $\mathrm{ABC}$ transporters that function as xenobiotic efflux pumps. Increased transporter expression and transport activity occurred after in vivo or in vitro exposure to the Nrf2 ligand SFN. In rats, SFN dosing (5-10 $\mathrm{mg} / \mathrm{kg}$ ) decreased by $40-50 \%$ brain accumulation of verapamil, a drug that is a P-glycoprotein substrate. This is approximately the same magnitude decrease in brain verapamil accumulation seen previously when P-glycoprotein expression increased two to three times through the action of the xenobiotic-activated nuclear receptors constitutive androstane receptor and $\mathrm{AhR}$ (Wang et al., 2010; Wang et al., 2011). Experiments with isolated brain capillaries established that SFN acted through Nrf2 (lack of SFN effect in capillaries from Nrf2-null mice) and that the increase in P-glycoprotein transport activity was abolished when transcription or translation was inhibited. We found similar increases in P-glycoprotein transport activity in mouse spinal cord capillaries exposed to SFN, indicating that, in both CNS barrier tissues, $\mathrm{P}$-glycoprotein is Nrf2 responsive.

More than 2000 genes are Nrf2 targets, although the pattern of Nrf2 effects is tissue specific (Copple et al., 2010; Copple, 2012). Certainly, the full extent of the response to Nrf2 activation at the blood-brain and blood-spinal cord barriers has been only partially defined. We show here increased expression of three ABC transporters and HO- 1 in brain capillaries from SFN-exposed rats. Previously, J. Zhao et al. (2006) found increased expression of the Nrf2 targets $\mathrm{HO}-1, \mathrm{GST} \alpha 3$, and NAD $(\mathrm{P}) \mathrm{H}$ quinine oxidoreductase in brain capillaries from SFN-exposed mice. Additional consequences of Nrf2 activation at these CNS barriers remain to be explored.

Presumably, increased efflux transport activity at CNS barriers is needed to remove products of ROS detoxification, e.g., GSH conjugates, formed as a result of increased enzyme activity. Indeed, previous work in cell models of the blood-brain barrier, in isolated brain capillaries, and in vivo showed that both exposure to hydrogen peroxide and depletion of glutathione increases P-glycoprotein expression (Felix and Barrand, 2002; Nwaozuzu et al., 2003). Given the present results, it is likely that Nrf2 activation was involved.

$\mathrm{P}$-glycoprotein and Bcrp are recognized as major impediments to CNS pharmacotherapy. Because they are critical gatekeepers for many CNS-acting drugs, they can substantially limit the ability of drugs to access sites of action in the CNS. For both transporters, increased expression at the blood-brain barrier further restricts drug uptake into the brain (Miller, 2010). Recent studies indicate that, for some classes of drugs, e.g., several tyrosine kinase inhibitors used as chemotherapeutics, these two transporters work together (Agarwal et al., 2011). Both transporters are expressed at the bloodspinal cord barrier (Campos et al., 2012); the extent to which they work together in that tissue is not clear. In view of the present findings for both CNS barriers, we suggest caution when intentionally activating Nrf2 for neuroprotection, because increased drug efflux transporter expression and possibly drug metabolizing enzyme activity would impair subsequent CNS pharmacotherapy.

The present study also discloses a novel sequence of events that drives Nrf2-induced increases in expression of P-glycoprotein and Bcrp (and possibly Mrp2) in rat and mouse brain and spinal cord capillaries (Fig. $8 B$ ). Inhibition of p53, p38 MAPK, or NF- $\kappa$ B abolished the SFN-induced increases in $\mathrm{ABC}$ transporter activity/expres-
B
WT Mice

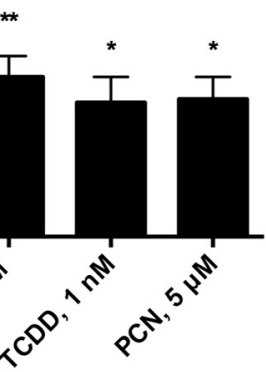

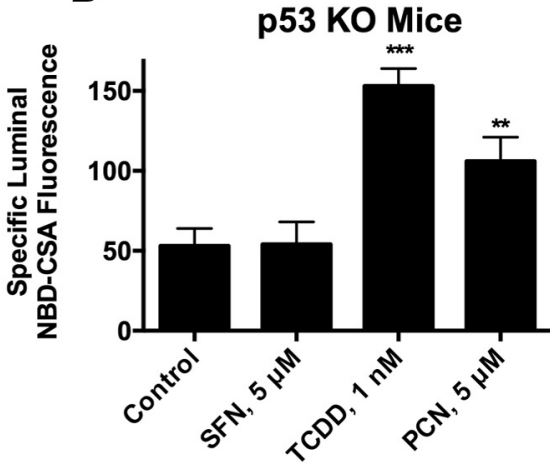

sion. Moreover, in isolated rat brain capillaries, the p53 inhibitor pifithrin blocked SFN-induced increases in transporter activity and protein expression. Conversely, the p53 activator nutlin-3 increased transport activity of P-glycoprotein. Consistent with those results, SFN exposure did not increase P-glycoprotein transport activity in brain and spinal cord capillaries from p53-null mice. In addition, inhibition of either p38 MAPK or NF- $\kappa$ B blocked the effects of SFN and nutlin-3 on transporter activity. Thus, in brain barrier tissues, activation of $\mathrm{p} 53, \mathrm{p} 38$, and NF- $\kappa \mathrm{B}$ was required for Nrf2 to signal increased transporter expression and activity.

In response to oxidative/electrophilic stress, Nrf2 can both signal and function as a transcription factor (Copple et al., 2010; Copple, 2012). Both p38 MAPK and NF- $\kappa$ B are known downstream targets of Nrf2 signaling (Wakabayashi et al., 2010; Schneider and Krämer, 2011; Copple, 2012). The novel combination disclosed here involves Nrf2 and p53. In cell models, depending on the expression level, p53 activation can be pro-oxidant or antioxidant (Vurusaner et al., 2012). However, there are no reports showing p53 as a target of Nrf2 signaling. In fact, several studies show Nrf2 and p53 to be mutually antagonistic. Clearly, this is not the case for regulation of $\mathrm{ABC}$ transporter expression at the blood-brain and blood-spinal cord barriers.

Although our experiments show that Nrf2, p53, p38, and NF- $\kappa$ B work in concert to change transporter expression, it is not clear how this happens. On the one hand, Nrf2, p53, and p38 MAPK could be the backbone of a cytoplasmic signaling pathway that leads to NF- $\kappa \mathrm{B}$ translocation and increased transporter expression. On the other hand, Nrf2, p53, and NF- $\kappa \mathrm{B}$ could be required to be present in the nucleus before transporter expression increases. The present results provide some guidance in this matter. In rat brain capillaries exposed to SFN, EMSA shows that Nrf2, p53, and NF- $\kappa$ B all translocate to the nucleus; immunostaining confirms this for NF- $\kappa \mathrm{B}$ and demonstrates the dependence of nuclear translocation on p53 and p38. However, in capillaries from Nrf2-null mice, the p53 activator nutlin-3 still increased P-glycoprotein transport activity, and inhibition of either $\mathrm{p} 38$ or NF- $\kappa \mathrm{B}$ abolished the p53-induced increases in activity. Thus, although SFN exposure leads to nuclear translocation of Nrf2, p53, and NF- $\kappa$ B, p53 does not require nuclear Nrf2 to increase P-glycoprotein expression, implying that Nrf2 signals to p53, which in turn activates p38. At present, it is not clear how Nrf2 activates $\mathrm{p} 53$ nor whether $\mathrm{p} 53$ is needed in the nucleus to support the action of NF- $\kappa$ B.

In summary, we show here that activating the oxidative/electrophilic stress sensor Nrf2 at the blood-brain and blood-spinal cord barrier increases protein expression and transport activity of three 
$\mathrm{ABC}$ transporters that can function as xenobiotic efflux pumps. In both barrier tissues, Nrf2 signals indirectly through p53, p38 MAPK, and NF- $\kappa$ B to increase transporter expression. Given the large number of therapeutic drugs handled by these efflux transporters, one would expect reduced CNS access and thus reduced drug efficacy when brain and spinal cord endothelial cells undergo oxidative stress or when Nrf2 is activated for neuroprotection.

\section{References}

Agarwal S, Hartz AM, Elmquist WF, Bauer B (2011) Breast cancer resistance protein and P-glycoprotein in brain cancer: two gatekeepers team up. Curr Pharm Des 17:2793-2802. CrossRef Medline

Aleksunes LM, Klaassen CD (2012) Coordinated regulation of hepatic phase I and II drug-metabolizing genes and transporters using AhR-, CAR-, PXR-, PPARalpha-, and Nrf2-null mice. Drug Metab Dispos 40: 1366-1379. CrossRef Medline

Aleksunes LM, Manautou JE (2007) Emerging role of Nrf2 in protecting against hepatic and gastrointestinal disease. Toxicol Pathol 35:459-473. CrossRef Medline

Alfieri A, Srivastava S, Siow RC, Modo M, Fraser PA, Mann GE (2011) Targeting the Nrf2-Keap1 antioxidant defence pathway for neurovascular protection in stroke. J Physiol 589:4125-4136. CrossRef Medline

Bauer B, Hartz AM, Fricker G, Miller DS (2004) Pregnane X receptor upregulation of $\mathrm{P}$-glycoprotein expression and transport function at the blood-brain barrier. Mol Pharmacol 66:413-419. Medline

Bauer B, Yang X, Hartz AM, Olson ER, Zhao R, Kalvass JC, Pollack GM, Miller DS (2006) In vivo activation of human pregnane-X receptor tightens the blood-brain barrier to methadone through P-glycoprotein upregulation. Mol Pharmacol 70:1212-1219. CrossRef Medline

Bauer B, Hartz AM, Pekcec A, Toellner K, Miller DS, Potschka H (2008a) Seizure-induced up-regulation of P-glycoprotein at the blood-brain barrier through glutamate and cyclooxygenase-2 signaling. Mol Pharmacol 73:1444-1453. CrossRef Medline

Bauer B, Hartz AM, Lucking JR, Yang X, Pollack GM, Miller DS (2008b) Coordinated nuclear receptor regulation of the efflux transporter, Mrp2, and the phase-II metabolizing enzyme, GSTpi, at the blood-brain barrier. J Cereb Blood Flow Metab 28:1222-1234. CrossRef Medline

Campos CR, Schröter C, Wang X, Miller DS (2012) ABC transporter function and regulation at the blood-spinal cord barrier. J Cereb Blood Flow Metab 32:1559-1566. CrossRef Medline

Cannon RE, Peart JC, Hawkins BT, Campos CR, Miller DS (2012) Targeting blood-brain barrier sphingolipid signaling reduces basal P-glycoprotein activity and improves drug delivery to the brain. Proc Natl Acad Sci U S A 109:15930-15935. CrossRef Medline

Chen G, Fang Q, Zhang J, Zhou D, Wang Z (2011) Role of the Nrf2-ARE pathway in early brain injury after experimental subarachnoid hemorrhage. J Neurosci Res 89:515-523. CrossRef Medline

Chen W, Jiang T, Wang H, Tao S, Lau A, Fang D, Zhang DD (2012) Does Nrf2 contribute to p53-mediated control of cell survival and death? Antioxid Redox Signal 17:1670-1675. CrossRef Medline

Cho HY, Kleeberger SR (2007) Genetic mechanisms of susceptibility to oxidative lung injury in mice. Free Radic Biol Med 42:433-445. CrossRef Medline

Copple IM (2012) The Keap1-Nrf2 cell defense pathway-a promising therapeutic target? Adv Pharmacol 63:43-79. CrossRef Medline

Copple IM, Goldring CE, Kitteringham NR, Park BK (2010) The keap1-nrf2 cellular defense pathway: mechanisms of regulation and role in protection against drug-induced toxicity. Handb Exp Pharmacol 233-266.

Dash PK, Zhao J, Orsi SA, Zhang M, Moore AN (2009) Sulforaphane improves cognitive function administered following traumatic brain injury. Neurosci Lett 460:103-107. CrossRef Medline

Felix RA, Barrand MA (2002) P-glycoprotein expression in rat brain endothelial cells: evidence for regulation by transient oxidative stress. J Neurochem 80:64-72. CrossRef Medline

Fox RJ, Miller DH, Phillips JT, Hutchinson M, Havrdova E, Kita M, Yang M, Raghupathi K, Novas M, Sweetser MT, Viglietta V, Dawson KT (2012) Placebo-controlled phase 3 study of oral BG-12 or glatiramer in multiple sclerosis. N Engl J Med [Erratum (2012) 367:1673] 367:1087-1097. CrossRef Medline

Gold R, Kappos L, Arnold DL, Bar-Or A, Giovannoni G, Selmaj K, Tornatore C, Sweetser MT, Yang M, Sheikh SI, Dawson KT (2012) Placebocontrolled phase 3 study of oral BG-12 for relapsing multiple sclerosis. N Engl J Med [Erratum 367:2362] 367:1098-1107. CrossRef Medline

Hartz AM, Bauer B, Fricker G, Miller DS (2004) Rapid regulation of
P-glycoprotein at the blood-brain barrier by endothelin-1. Mol Pharmacol 66:387-394. CrossRef Medline

Hawkins BT, Sykes DB, Miller DS (2010) Rapid, reversible modulation of blood-brain barrier P-glycoprotein transport activity by vascular endothelial growth factor. J Neurosci 30:1417-1425. CrossRef Medline

Klaassen CD, Slitt AL (2005) Regulation of hepatic transporters by xenobiotic receptors. Curr Drug Metab 6:309-328. CrossRef Medline

Li B, Liu S, Miao L, Cai L (2012) Prevention of diabetic complications by activation of Nrf2: diabetic cardiomyopathy and nephropathy. Exp Diabetes Res 2012:216512. CrossRef Medline

Linker RA, Lee DH, Ryan S, van Dam AM, Conrad R, Bista P, Zeng W, Hronowsky X, Buko A, Chollate S, Ellrichmann G, Brück W, Dawson K, Goelz S, Wiese S, Scannevin RH, Lukashev M, Gold R (2011) Fumaric acid esters exert neuroprotective effects in neuroinflammation via activation of the Nrf2 antioxidant pathway. Brain 134:678-692. CrossRef Medline

Maher JM, Cheng X, Slitt AL, Dieter MZ, Klaassen CD (2005) Induction of the multidrug resistance-associated protein family of transporters by chemical activators of receptor-mediated pathways in mouse liver. Drug Metab Dispos 33:956-962. CrossRef Medline

Mao L, Wang HD, Wang XL, Tian L, Xu JY (2012) Disruption of Nrf2 exacerbated the damage after spinal cord injury in mice. J Trauma Acute Care Surg 72:189-198. CrossRef Medline

Miller DS (2010) Regulation of P-glycoprotein and other ABC drug transporters at the blood-brain barrier. Trends Pharmacol Sci 31:246-254. CrossRef Medline

Miller DS, Nobmann SN, Gutmann H, Toeroek M, Drewe J, Fricker G (2000) Xenobiotic transport across isolated brain microvessels studied by confocal microscopy. Mol Pharmacol 58:1357-1367. CrossRef Medline

Nwaozuzu OM, Sellers LA, Barrand MA (2003) Signalling pathways influencing basal and $\mathrm{H}(2) \mathrm{O}(2)$-induced P-glycoprotein expression in endothelial cells derived from the blood-brain barrier. J Neurochem 87: 1043-1051. CrossRef Medline

Paine A, Eiz-Vesper B, Blasczyk R, Immenschuh S (2010) Signaling to heme oxygenase- 1 and its anti-inflammatory therapeutic potential. Biochem Pharmacol 80:1895-1903. CrossRef Medline

Rotblat B, Melino G, Knight RA (2012) NRF2 and p53: Januses in cancer? Oncotarget 3:1272-1283. Medline

Schneider G, Krämer OH (2011) NFkappaB/p53 crosstalk-a promising new therapeutic target. Biochim Biophys Acta 1815:90-103. CrossRef Medline

Schramm U, Fricker G, Wenger R, Miller DS (1995) P-glycoproteinmediated secretion of a fluorescent cyclosporin analogue by teleost renal proximal tubules. Am J Physiol 268:F46-F52. Medline

Vurusaner B, Poli G, Basaga H (2012) Tumor suppressor genes and ROS: complex networks of interactions. Free Radic Biol Med 52:7-18. CrossRef Medline

Wakabayashi N, Slocum SL, Skoko JJ, Shin S, Kensler TW (2010) When NRF2 talks, who's listening? Antioxid Redox Signal 13:1649-1663. CrossRef Medline

Wang X, Sykes DB, Miller DS (2010) Constitutive androstane receptormediated up-regulation of ATP-driven xenobiotic efflux transporters at the blood-brain barrier. Mol Pharmacol 78:376-383. CrossRef Medline

Wang X, Hawkins BT, Miller DS (2011) Aryl hydrocarbon receptormediated up-regulation of ATP-driven xenobiotic efflux transporters at the blood-brain barrier. FASEB J 25:644-652. CrossRef Medline

Wang X, de Rivero Vaccari JP, Wang H, Diaz P, German R, Marcillo AE, Keane RW (2012) Activation of the nuclear factor E2-related factor 2/antioxidant response element pathway is neuroprotective after spinal cord injury. J Neurotrauma 29:936-945. CrossRef Medline

Wang X, Cabrera RM, Li Y, Miller DS, Finnell RH (2013) Functional regulation of P-glycoprotein at the blood-brain barrier in proton-coupled folate transporter (PCFT) mutant mice. FASEB J 27:1167-1175. CrossRef Medline

Wang Z, Ma C, Meng CJ, Zhu GQ, Sun XB, Huo L, Zhang J, Liu HX, He WC, Shen XM, Shu Z, Chen G (2012) Melatonin activates the Nrf2-ARE pathway when it protects against early brain injury in a subarachnoid hemorrhage model. J Pineal Res 53:129-137. CrossRef Medline

Yan W, Wang HD, Hu ZG, Wang QF, Yin HX (2008) Activation of Nrf2ARE pathway in brain after traumatic brain injury. Neurosci Lett 431: 150-154. CrossRef Medline

Zhao B, Baston DS, Hammock B, Denison MS (2006) Interaction of diuron and related substituted phenylureas with the Ah receptor pathway. J Biochem Mol Toxicol 20:103-113. CrossRef Medline

Zhao J, Kobori N, Aronowski J, Dash PK (2006) Sulforaphane reduces infarct volume following focal cerebral ischemia in rodents. Neurosci Lett 393:108-112. CrossRef Medline 